\title{
It Is Never too Late to Learn: The Role of Organizational Support in Older Employees' Learning
}

\author{
JANA ŽNIDARŠIČ \\ School of Economics and Business \\ University of Ljubljana \\ Ljubljana, Slovenia
}

\author{
Original Scientific Paper \\ UDK: 331.105.2-053.9 \\ doi: $10.3935 /$ rsp.v28i2.1730 \\ Received: April 2020
}

\section{MOJCA KOGOVŠEK \\ METKA KOGOVŠEK}

Grm Novo mesto - Centre of Biotechnics and Tourism

Novo mesto, Slovenia

\section{IRENA OGRAJENŠEK}

School of Economics and Business

University of Ljubljana

Ljubljana, Slovenia

For last decades, lifelong-learning has been receiving growing attention as playing a crucial role in active ageing social policies. Due to numerous controversial research findings regarding older employees' continuous learning, our work focuses on comparing older vs. younger employees in terms of their motivation (willingness) to learn and outcomes that result from learning and training processes. Our results do not show statistically significant differences in learning results of both groups of employees, neither nor in general motivation for learning. However, the results show that older employees engage in learning less to fulfil their career goals and more to improve their work efficiency as well as facilitate knowledge transfer to the workplace. The crucial role of perceived organizational support for older employees' continuous learning and training at workplace is further discussed.

Key words: workforce aging, older employees, motivation for learning, age management.

* Jana Žnidaršič, University of Ljubljana, School of Economics and Business, Kardeljeva ploščad 17, 1000 Ljubljana, Slovenija, jana.znidarsic@ef.uni-lj.si 


\section{INTRODUCTION}

The implications of population ageing ask for comprehensive and multidimensional approach of age management on individual, organizational and national level. The need to reduce early retirement and prolong employees' working lives has become a major goal on social policy agendas (Hasselhorn \& Apt, 2015), where active ageing is most commonly linked to continued (lifelong) learning (OECD, 2017).

Coming to older employees learning, we face several challenges that trigger our research. Even though many scholars (Kooij, 2015; Tims, Bakker, \& Kerks, 2013; Wang, Olson, \& Shultz, 2013) stress the need to identify the HRM strategies that stimulate the older employees' learning, research on learning and training of older employees in terms of their employability is still rather limited (Picchio and van Ours, 2013). Midtsundstad (2019) even warns that we still need to answer the question whether adult learning and training increase the number of years in employment amongst older workers, nevertheless other researchers (e.g. Armstrong-Stassen and Cattaneo, 2010) claim that the capabilities of aging employees are a key decision determinant of whether an individual stays or needs to leave a company.

Numerous age-stereotypes regarding older employees' learning, like conviction about their lower learning capabilities, inevitable rapid linear cognitive decline, and being uninterested in learning, only make situation worse. Even though, researchers (e.g. Axelrad, Luski and Miki, 2013) argue that bias age stereotypes mostly do not reflect the real characteristics of a certain agegroup, and we see some positive changes regarding age-stereotypic preconceptions about the learning ability of older workers (Heckhausen et al., 2017), persistent age stereotypes are still big stumbling blocks for retention and development of older employees (Gaillard \& Desmette, 2010). Tra- ditionally, younger employees seem to be more valuable for organisations than the older ones.

Moreover, research findings regarding older employees' motivation for learning, learning abilities and results are ambiguous and often contradicting. Numerous scholars reveal that older employees' motivation to learn remains constant over the life course (Bal \& Dorenbosch, 2015; Gegenfurtner \& Vauras, 2012; Kerman \& Keenan, 2017; Setti, Dordoni, Piccoli, Bellotto, \& Argentero, 2015; Wanberg, Kanfer, Hamann, \& Zhang, 2016). Similarly, Bertolino, Truxillo and Fraccaroli (2011) did not find that older workers were less interested in training, but rather that they expected fewer benefits to their careers from training.

However, there are other authors (e.g. Hashim \& Wok, 2014; Ng and Feldman, 2012), who agree that older workers' learning motivation decline while aging. According to socio-emotional selectivity theory - SST (Carstensen, 1995), younger adults place greater emphasis on knowledge gathering and career development, whereas older adults prioritize emotionally meaningful goals (Lang \& Carstensen, 2002). From older employees' perspective, additional learning and training would not pay-off due to shorter perceived time left in life (and at work).

Anyway, goal preferences are subject to contextual factors and can be changed. Within current research we test the role of perceived organizational support for older employees' learning, since employers' interventions may result in subtle changes in the emotional framing of attitudes towards learning that influence also learning outcomes.

Even though, specifying who is (and who is not), an older worker remains elusive; the answer to the question depends on the context (Pitt-Catsouphes \& Smyer, 2005). In studies concerning labor market participation, the term "older worker" usu- 
ally refers to workers aged 50 or 55 and above, because this age range corresponds to a decline in the participation rate in the labor market (OECD, 2005). Researchers examining older people in organizations, on the other hand, often put the threshold at 40 or 45, seeing "old" as referring to obsolete knowledge, skills, and attitudes (Muijnck \& Zwinkels, 2002). Considering the context of our current paper, we have put the age of 45 , distinguishing between younger and older employees.

In current study, we aim to examine (and answer) some continuously challenging questions regarding older employees' learning, namely: 1) If and how older workers learning motivation decline and are there any differences regarding intrinsic/extrinsic motivation for learning; 2) Do older workers really achieve worse learning results in comparison to their younger counterparts; 3) Do older workers receive the same organizational support for learning (compared to the group of younger workers) and how much relevant this support seems to be for older employees?

By further investigating into younger vs. older employees' motivation for learning, results of learning and different elements of perceived organizational support for learning, our paper finally brings an answer on an essential question: "How can perceived organizational support influence on older employees' perception about being ever too late to learn"? Our research findings add value to modern HRM theory; while simultaneously help practitioners by offering practical proposals - measures that rise learning performance of employees, regardless of their age.

The paper is structured into five sections. After the introduction, the second section presents theoretical background together with hypotheses development. The third chapter depicts methodological framework deployed in the paper, while the fourth presents the results. The final section closes with the implications, concluding thoughts with suggestions for further research in the field of interest.

\section{THEORETICAL BACKGROUND AND HYPOTHESES DEVELOPMENT}

\section{Self-determination theory, socio- emotional selectivity theory and older employees' intrinsic vs. extrinsic motivation for learning}

The individuals are motivated by the activities and results that are highly valued by them while the values are important determinants of one's behaviour (Maslow, 1943). Motivational reinforcement is of various resource, namely material, social and self-reinforcement (Bandura, 1971). Learning motivation encompasses the motivation to engage in learning, motivation to invest enough effort in the learning process and the motivation to transfer the newly acquired knowledge to the workplace $(\mathrm{Ge}$ genfurtner \& Vauras, 2012).

Intrinsic learning motivation is a self-determined motivation that brings enjoyment to the individual throughout the very learning process (Guerrero and Sire, 2001) where freedom and autonomy emanate from an individual inner self that satisfies his/her psychological needs (Ryan and Deci, 2000). The intrinsically motivated learners choose to engage in learning because of the desire for knowledge (Hvalič Erzetič, 2014), to strengthen self-confidence, to improve efficiency level at work, and to more easily adapt to changes at work which result in increased job autonomy (Guerrero and Sire, 2001). Similarly, Self-determination theory (SDT), developed by Ryan and Deci (2000a), proposes that humans are inherently motivated to develop their interests and skills, to connect and contribute to other people, and to move towards their fullest potential, as long as they simultaneously fulfil three main intrinsic needs, namely: for 
autonomy (to be self-regulating, to be the maker or at least the owner of one's choices); competence (to be effective in what one does, mastering new skills in the process); and relatedness (to feel connected and in sympathy with at least some others).

Extrinsic learning motivation is related to external gains that an individual receives, namely the opportunity for career development in the coming years (Bertolino, Truxillo and Fraccaroli, 2011), gaining recognition and salary raise (Griffin, 2011), or the guarantee that one can keep the current job (Minbaeva, 2008). Extrinsic motivation only prevents dissatisfaction but does not enhance satisfaction. Consequently, an individual might not be highly committed to the learning process which may consequently result in poorer learning results. While maturing, the importance of extrinsic motivation mostly weakens (Bal and Dorenbosch, 2015). This is also supported by Socio-emotional selectivity theory - SST (Carstensen, 1995), which reveals that younger adults place greater emphasis on knowledge gathering and career development, whereas older adults prioritize emotionally meaningful goals (Lang $\&$ Carstensen, 2002). According to SST, the relative priority of different socioemotional goals changes as a function of perceived time left in life. If so, from older employees' perspective, additional learning and training would not pay-off due to (more or less short) perceived time left in (working) life.

Adding some other research findings on older workers learning motivation (Bertolino, Truxillo and Fracaroli, 2011, Ng and Feldman, 2012) that also agree upon older workers' learning motivation decline while aging, we therefore posit the first set of hypotheses, namely:

Hla: 'Younger employees express higher levels of motivation (intrinsiclextrinsic) for learning and training at work, in comparison to their older counterparts.'
Hlb: 'Motivation (intrinsiclextrinsic), contributing to results (effects) of learning, is more relevant for younger employees then for older ones.'

\section{Learning outcomes/results}

Kirkpatrick and Kirkpatrick (2006) introduce the four-level evaluation model which offers several indicators of learning results, namely: a) the evaluation of the trainees' reactions to the learning process (first level), b) the learning objectives assessment (second level), c) the alteration of the learners' behaviour and intentions about learning transfer, d) the results such as increased productivity, increased sales, higher morale, employee retention, financial scores, and so on.

Many other authors (e.g., Aguinis \& Kraiger, 2009; Dermol, 2010; Fregonese, Caputo \& Langher, 2018) expand the Kirkpatricks' levels of training evaluation, by adding indicators, such as non-financial outcomes from learning, while considering individual as well as organizational benefits. Learning enables employees to achieve higher levels of productivity and efficiency at work (Hvalič Erzetič, 2014; Rejc Buhovac, 2010), to better adapt to new circumstances (Salas et al., 2012), to improve learners' problem solving skills and ability to take part in developmental activities within companies (Bertolino, Truxillo and Fraccaroli, 2011). Van Gerwen, Buskens and van der Lippe (2018) show that learning is even correlated with increased intentions for helping co-workers and better knowledge transfer (Bertolino, Truxillo and Fraccaroli, 2011) and the very presence of training programs is also related to organizational and technological changes (Neirotti and Paolucci, 2013).

When examining the differences between younger and older workers, researchers (like Bertolino, Truxillo and Fraccaroli, 2011; Hashim and Wok, 2014) mostly confirm correlation between age-related 
motivation decline and performance. Freund (2006) agrees that younger individuals mostly try hard to optimize performance while older individuals focus on minimizing losses, which is also supported by socio-emotional selectivity theory (Lang \& Carstensen, 2002). Therefore, we posit the second hypothesis:

H2: 'Younger employees achieve better learning results in comparison to their older counterparts.'

\section{Perceived organizational support for learning}

Carral and Alcover (2019) report that age discrimination is negatively related to perceived supervisors' as well as the co-workers' support. Moreover, negative views on aging workers might elicit self-stereotyping believes of older workers themselves as being incompetent in terms of developing desired results (Harris, Krygsman, Waschenko \& Laliberte Rudman, 2018; Voss, Wolff \& Rothermund, 2017). Contrary, as stated by Gaillard and Desmette (2010), when an older worker is exposed to positive stereotypic information, he/she expresses higher levels of motivation for learning.

Assuming that older workers tend to be less willing to participate in training and learning activities, this lack of willingness can be related to the absence of a supportive learning climate (Froehlich, Segers, \& van den Bossche, 2014; Stamov Roßnagel \& Jeske, 2017) or design of training that does not offer the optimal learning opportunities for older workers (Jeske \& Stamov Roßnagel, 2016).

Ryan and Deci (2000) talk about the significance of the social context that serves as the tools that elicits individual's perception of competence and autonomy that consequently supports an individual to become self-determined not just intrinsically, but also extrinsically motivated learner. Not only the supervisors' support for learning but also the colleagues' trust is of great significance (Gegenfurtner and Vauras 2012; Diamantidis and Chatzoglou, 2014). Supervisor and co-workers' support for learning correlates with work-environment learning transfer factors (Burmeister et al., 2019; Chatterjee, Pereira and Bates, 2018; Diamantidis and Chatzoglou, 2014; Massenberg, Spurk and Kauffeld, 2015; Salas et al., 2012) and even with lower learning anxiety (Spagnoli, Caetano and Santos, 2012), while supervisors' support for learning is especially important for the individuals with lower learning motivation, who therefore need stronger encouragement within positive organizational culture (Froehlich, Segers, \& van den Bossche, 2014). In this context, employers' support might be especially important when it comes to older employees (Charness \& Czaja, 2019; Jeske \& Stamov-Roßnagel, 2015; Olson \& Jeske, 2019). On the basis of literature review, Rudolph and Zacher (2015) suggest that vulnerability of older workers might be mitigated simply by (perceived) positive leadership support.

Within older workers' learning context in current research, the term 'perceived organizational support for learning' consists of perceived supervisor's encouragement and support (while also clearly acknowledging employees' transfer of the newly acquired knowledge to the workplace) and perceived peer support and encouragement (appreciating co-workers who transfer newly acquired knowledge to the workplace).

Although many researchers (e.g., BaylSmith \& Griffin, 2014) call for inclusionary practices based upon increased support for older workers, employers usually do not offer the optimal learning opportunities for older workers (Jeske \& Stamov Roßnagel, 2016). Therefore, the third group of hypotheses is as follows:

H3a: 'Perceived organizational support for learning is lower for the group of older 
workers compared to the group of younger workers.'

H3b: 'Perceived organizational support that contributes to results (effects) of learning is more relevant for older workers.'

We present our research model with hypotheses in Figure 1. mostly designed in a way that the respondents were expected to indicate their agreement with certain claim on a Likert scale.

The claims within our questionnaire that helped us to get dipper insight into motivation for learning were adapted upon Bertoli-

Figure 1

Hypothesized model

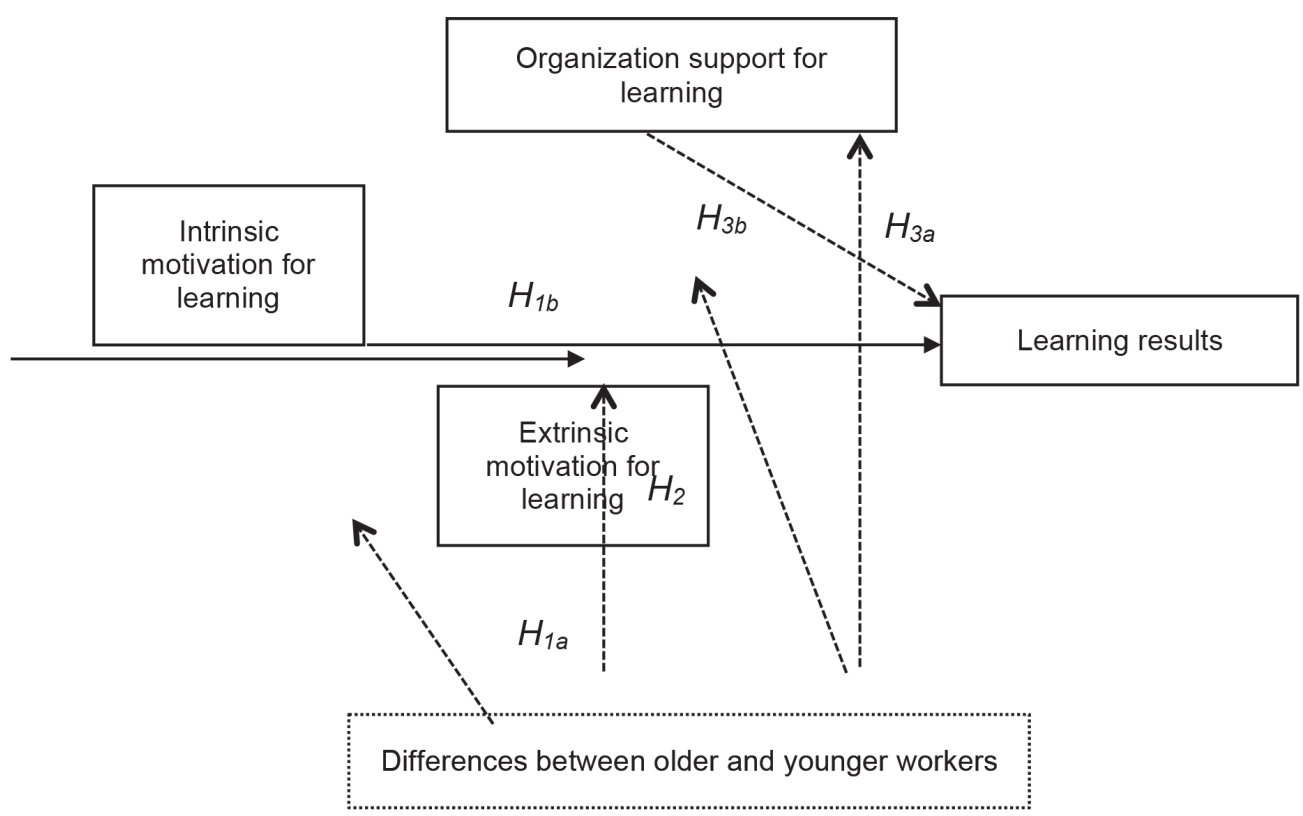

\section{METHODOLOGY AND \\ DATA}

\section{Research instrument}

The principal research instrument is an anonymous questionnaire that enables a collection of the data on broader aspects of workplace learning. The questionnaire consisted of 72 statements (of which 21 items are relevant for the current study), no, Truxillo and Fraccaroli (2011), Guerrero and Sire (2001) and Kastelec (2013), while perceived organizational support for learning were adapted upon Dermol (2010). Part of the study on workplace learning results followed the Kirkpatrick and Kirkpatrick four-level model typology (Kirkpatrick and Kirkpatrick, 2006) while adapting several authors' indicators of learning results, as evident from Table 1. 
Table 1

The questionnaire items and authors

\begin{tabular}{|c|c|}
\hline Items & \multirow{2}{*}{ Author(s) } \\
\hline Indicators of intrinsic motivation for learning & \\
\hline Attendance at learning program brings me personal satisfaction & Guerrero \& Sire, 2001 \\
\hline I attended the learning program because of my desire for knowledge & Guerrero \& Sire, 2001 \\
\hline I attended the learning program to strengthen self-confidence & Guerrero \& Sire, 2001 \\
\hline I attended the learning program to improve my efficiency level at work & Guerrero \& Sire, 2001 \\
\hline $\begin{array}{l}\text { I attended the learning program to adapt more easily to changes at } \\
\text { work }\end{array}$ & Guerrero \& Sire, 2001 \\
\hline I attended the learning program to increase autonomy at work & Guerrero \& Sire, 2001 \\
\hline I will be able to transfer newly acquired knowledge to my workplace & $\begin{array}{l}\text { Bertolino, Truxillo \& } \\
\text { Fraccaroli, } 2011\end{array}$ \\
\hline \multicolumn{2}{|l|}{ Indicators of extrinsic motivation for learning } \\
\hline I attended the learning program to get the opportunity for salary raise & Guerrero \& Sire, 2001 \\
\hline I attended the learning program to get promotion opportunity & Guerrero \& Sire, 2001 \\
\hline I attended the learning program to keep my current job & Kastelec, 2013 \\
\hline I attended the learning program to earn respect from the organization & Kastelec, 2013 \\
\hline \multicolumn{2}{|l|}{ Indicators of perceived organizational support for learning } \\
\hline My supervisor encourages me to learn & Dermol, 2010 \\
\hline $\begin{array}{l}\text { My supervisor clearly acknowledges my transfer of the newly acquired } \\
\text { knowledge to the workplace }\end{array}$ & Dermol, 2010 \\
\hline My co-workers encourage me to learn & Dermol, 2010 \\
\hline $\begin{array}{l}\text { In my organization. employees appreciate co-workers who transfer } \\
\text { newly acquired knowledge to the workplace }\end{array}$ & Dermol, 2010 \\
\hline \multicolumn{2}{|l|}{ Indicators of learning results } \\
\hline I transferred the newly acquired knowledge to my workplace. & $\begin{array}{l}\text { Bertolino, Truxillo and } \\
\text { Fraccaroli, } 2011\end{array}$ \\
\hline $\begin{array}{l}\text { By the newly acquired knowledge I am able to contribute in terms of } \\
\text { enhanced working processes. }\end{array}$ & Hvalič Erzetič, 2014 \\
\hline $\begin{array}{l}\text { I have become more capable therefore I have the opportunity to } \\
\text { participate in developmental activities. }\end{array}$ & $\begin{array}{l}\text { Bertolino, Truxillo and } \\
\text { Fraccaroli, } 2011\end{array}$ \\
\hline Through learning program I managed to develop problem solving skills. & $\begin{array}{l}\text { Bertolino, Truxillo and } \\
\text { Fraccaroli, } 2011\end{array}$ \\
\hline The learning program enhanced my efficiency at work. & Rejc Buhovac, 2010 \\
\hline The learning program enabled me to more easily adapt to changes. & Hvalič Erzetič, 2014 \\
\hline
\end{tabular}

The achieved level of education might be correlated to motivation for learning as well as learning results (Kump \& Jelenc Krašovec, 2010). Therefore, it is used as a control variable.

\section{Sample}

The study is conducted using the purposive sampling, choosing the three for-profit companies that have been successfully implementing age management measures for 
several years, including implementation of training (learning) programs that included all employees. These three companies were chosen also on the basis of our (authors') previous fruitful cooperation with HRM staff in these companies, when researching age management practices on company level (Žnidaršič, 2008).

These three companies include: 1) the first one is a big multinational company, founded in 1902 and nowadays, offering over 60,000 products that are used in homes, businesses, schools, hospitals, and for learning by the employer. Moreover, those employees may be more inclined to retire as soon as possible, which means that HR managers need to put more efforts into motivating them to prolong their working lives.

Namely, 69 employees are employed by the first company, a company that delivers to customers the innovative products and services, 89 employees are employed by car assembly, and 101 employees are employed by a coal mining company as evident from Table 2.

Table 2

The age structure of a sample

\begin{tabular}{lcccccr}
\hline & $\begin{array}{c}\text { Number of } \\
\text { respondents }\end{array}$ & $\begin{array}{c}\text { Share } \\
(\%)\end{array}$ & $\begin{array}{c}\text { Number of } \\
\text { younger } \\
\text { respondents }\end{array}$ & $\begin{array}{c}\text { Share } \\
(\%)\end{array}$ & $\begin{array}{c}\text { Number of older } \\
\text { respondents }\end{array}$ & $\begin{array}{c}\text { Share } \\
(\%)\end{array}$ \\
\hline Multinational company & 69 & $27 \%$ & 49 & $31 \%$ & 20 & $19 \%$ \\
\hline Car manufacturer & 89 & $34 \%$ & 45 & $29 \%$ & 44 & $43 \%$ \\
\hline Coal mining company & 101 & $39 \%$ & 62 & $40 \%$ & 39 & $38 \%$ \\
\hline Total & 259 & $100 \%$ & 156 & $100 \%$ & 103 & $100 \%$ \\
\hline
\end{tabular}

other industries. The company is present in 70 countries and sales in 200. It employs over 93,000 workers globally (we had contacts with its Slovenian subsidiary); 2) the second is one of the largest Slovenian companies, a car manufacturer and one of the largest exporters (it employs over 2,500 workers and was established in 1988 as a joint venture with one foreign car producer); 3 ) the third company is a coal mining company that employs over 1,200 workers (it is based on advanced technology and it earned ISO 50001 standard as the first coal mining company in Slovenia).

Chosen companies are interesting for our research, because they are all labour-intensive industries, where the majority of workers are not highly educated. Mostly, they do not get involved in learning and on the job training by nature (by themselves), they need to be encouraged
All the employees, invited to take part in the research, agree upon the request and complete the survey questionnaire after successfully finishing their respected training courses. Some of the courses are about general training (language courses, team building events, ICT courses), while others focus on developing specific knowledge and skills (anti-explosion protection courses, the technical-control employees' courses).

The questionnaire was completed by a diverse group of employees of several occupations (miners, sales representatives etc.), different levels of education, age, and tenure. The sample consists of 103 older employees (aged 45 and more) and 156 younger employees (up to 45 years of age).

Descriptive statistics regarding the features of both age-groups of employees are shown in Table 3. 
Table 3

Descriptive statistics for the group of older and younger employees

\begin{tabular}{|c|c|c|}
\hline Variable & Frequency & Percent \\
\hline \multicolumn{3}{|l|}{ Older employees } \\
\hline \multicolumn{3}{|l|}{ Gender } \\
\hline Male & 65 & 63.10 \\
\hline Female & 38 & 36.90 \\
\hline Total & 103 & 100.00 \\
\hline \multicolumn{3}{|l|}{ Education } \\
\hline Three-year vocational education & 18 & 17.50 \\
\hline Secondary education & 30 & 29.10 \\
\hline Upper-secondary vocational program & 13 & 12.60 \\
\hline $1^{\text {st }}$ Bologna cycle or equivalent & 17 & 16.50 \\
\hline $2^{\text {nd }}$ Bologna cycle or equivalent & 24 & 23.30 \\
\hline Master of science program or equivalent & 1 & 1.00 \\
\hline Total & 103 & 100.00 \\
\hline \multicolumn{3}{|l|}{ Tenure } \\
\hline From 6 months up to 1 year & 2 & 1.90 \\
\hline From 1 year up to 5 years & 1 & 1.00 \\
\hline From 5 years up to 10 years & 5 & 4.90 \\
\hline From 10 years up to 25 years & 21 & 20.40 \\
\hline More than 25 years & 74 & 71.80 \\
\hline Total & 103 & 100.00 \\
\hline \multicolumn{3}{|l|}{ Younger employees } \\
\hline \multicolumn{3}{|l|}{ Gender } \\
\hline Male & 90 & 57.70 \\
\hline Female & 66 & 42.30 \\
\hline Total & 156 & 100.00 \\
\hline \multicolumn{3}{|l|}{ Education } \\
\hline Three-year vocational education & 21 & 13.50 \\
\hline Secondary education & 48 & 30.80 \\
\hline Upper-secondary vocational program & 18 & 11.50 \\
\hline $1^{\text {st }}$ Bologna cycle or equivalent & 28 & 17.90 \\
\hline $2^{\text {nd }}$ Bologna cycle or equivalent & 37 & 23.70 \\
\hline Master of science program or equivalent & 4 & 2.60 \\
\hline Total & 156 & 100.00 \\
\hline \multicolumn{3}{|l|}{ Tenure } \\
\hline Up to 6 months & 4 & 2.60 \\
\hline From 6 months up to 1 year & 5 & 3.20 \\
\hline From 1 year up to 5 years & 29 & 18.60 \\
\hline From 5 years up to 10 years & 31 & 19.90 \\
\hline From 10 years up to 25 years & 80 & 51.30 \\
\hline More than 25 years & 6 & 3.80 \\
\hline Missing value & 1 & 0.60 \\
\hline Total & 156 & 100.00 \\
\hline
\end{tabular}


There were more male than female respondents in both age groups of employees, while all of the respondents have completed minimum three-year vocational education while one of the older employees and four of the younger employees achieved even the master in science programs. Above $70 \%$ of older employees have worked for the company for more than 25 years whereas more than half of the younger employees have worked for the company for more than 10 years.

\section{Data analysis}

Besides descriptive statistics, we applied the independent t-test for identifying the mean differences between the two groups of employees (younger vs. older) on the field of investigation. Then, we used regression analysis to test the relationships among focal constructs, namely learning (motivational, contextual) drivers and learning results.

\section{RESULTS}

The results do not show statistically significant differences in intrinsic learning motivation between the two age groups of workers. Older employees are equally inclined (motivated) towards learning and training at work as their younger colleagues when it comes to intrinsic learning motivation. However, younger employees express stronger extrinsic learning motivation in terms of getting promoted (younger employees' mean $=2.72$; older employees' mean $=2.29, \mathrm{p}<0.01$ ) and earning respect from the company (younger employees' mean $=2.96$, older employees' mean $=$ $2.65, \mathrm{p}<0.05)$. The older employees do not attend learning courses to get promoted or earn respect as much as the younger employees do. Thus, the H1a hypothesis is partially supported.

Younger employees also express higher agreement of getting support for learning by their co-workers (younger employees' mean $=3.14$, older employees' mean $=2.86, \mathrm{p}<$ $0.05)$. Further, the H3a hypothesis is supported because younger employees indeed get more support for learning as evident from Table 4.

Table 4

Differences in the younger versus the older employees' learning variables

\begin{tabular}{|c|c|c|c|c|c|}
\hline \multirow[t]{2}{*}{ Learning variables } & \multicolumn{2}{|c|}{$\begin{array}{l}\text { Younger } \\
\text { employees }\end{array}$} & \multicolumn{2}{|c|}{$\begin{array}{c}\text { Older } \\
\text { employees }\end{array}$} & \multirow[t]{2}{*}{ t-value } \\
\hline & M & SD & M & SD & \\
\hline \multicolumn{6}{|l|}{ Intrinsic learning motivation } \\
\hline $\begin{array}{l}\text { Attendance at learning program brings me personal } \\
\text { satisfaction }\end{array}$ & 4.02 & 0.796 & 3.99 & 0.875 & 0.277 \\
\hline $\begin{array}{l}\text { I attended the learning program because of my desire for } \\
\text { knowledge }\end{array}$ & 4.17 & 0.893 & 4.08 & 0.825 & 0.780 \\
\hline $\begin{array}{l}\text { I attended the learning program to strengthen self- } \\
\text { confidence }\end{array}$ & 3.37 & 1.088 & 3.31 & 1.120 & 0.465 \\
\hline $\begin{array}{l}\text { I attended the learning program to improve my efficiency } \\
\text { level at work }\end{array}$ & 4.04 & 0.915 & 4.12 & 0.778 & -0.728 \\
\hline $\begin{array}{l}\text { I attended the learning program to adapt more easily to } \\
\text { changes at work }\end{array}$ & 3.76 & 0.986 & 3.75 & 0.805 & 0.097 \\
\hline $\begin{array}{l}\text { I attended the learning program to increase autonomy at } \\
\text { work }\end{array}$ & 3.69 & 1.004 & 3.65 & 0.951 & 0.345 \\
\hline $\begin{array}{l}\text { I will be able to transfer newly acquired knowledge to my } \\
\text { workplace }\end{array}$ & 4.24 & 0.838 & 4.27 & 0.773 & 0.275 \\
\hline
\end{tabular}




\begin{tabular}{|c|c|c|c|c|c|}
\hline \multirow[t]{2}{*}{ Learning variables } & \multicolumn{2}{|c|}{$\begin{array}{l}\text { Younger } \\
\text { employees }\end{array}$} & \multicolumn{2}{|c|}{$\begin{array}{l}\text { Older } \\
\text { employees }\end{array}$} & \multirow[t]{2}{*}{ t-value } \\
\hline & M & SD & M & SD & \\
\hline \multicolumn{6}{|l|}{ Extrinsic learning motivation } \\
\hline $\begin{array}{l}\text { I attended the learning program to get the opportunity for } \\
\text { salary raise }\end{array}$ & 2.44 & 1.230 & 2.18 & 1.161 & 1.688 \\
\hline $\begin{array}{l}\text { I attended the learning program to get promotion } \\
\text { opportunity }\end{array}$ & 2.72 & 1.304 & 2.29 & 1.134 & $0.802^{\star *}$ \\
\hline I attended the learning program to keep my current job & 2.72 & 1.232 & 2.72 & 1.300 & 0.054 \\
\hline $\begin{array}{l}\text { I attended the learning program to earn respect from the } \\
\text { organization }\end{array}$ & 2.96 & 1.109 & 2.65 & 1.096 & $2.192^{*}$ \\
\hline \multicolumn{6}{|l|}{ Perceived organizational support for learning } \\
\hline My supervisor encourages me to learn & 3.71 & 1.077 & 3.62 & 1.169 & 0.679 \\
\hline $\begin{array}{l}\text { My supervisor clearly acknowledges my transfer of the } \\
\text { newly acquired knowledge to the workplace }\end{array}$ & 3.51 & 1.092 & 3.41 & 1.037 & 0.694 \\
\hline My co-workers encourage me to learn & 3.14 & 1.019 & 2.86 & 0.990 & $2.173^{*}$ \\
\hline $\begin{array}{l}\text { In my organization. employees appreciate co-workers } \\
\text { who transfer newly acquired knowledge to the workplace }\end{array}$ & 3.51 & .969 & 3.34 & 0.990 & 1.336 \\
\hline
\end{tabular}
${ }^{*} p<0.05 ;{ }^{* *} p<0.01$

The results do not support the second hypothesis (H2), since they do not show statistically significant differences in learning results of older versus younger employees except for the stronger older employees' ability to adapt to changing work environment after learning (older employees' mean $=3.76$, younger employees' mean $=3.53, \mathrm{p}<0.05$ ). The results (effects) of learning at work are the same regardless of employees' age. The group of older employees indicated a stronger ability to adapt to changing work environment, as evident from Table 5 .

Table 5

Differences in the younger versus the older employees' learning results

\begin{tabular}{lccccc}
\hline Learning results variables & $\begin{array}{c}\text { Younger } \\
\text { employees }\end{array}$ & $\begin{array}{c}\text { Older } \\
\text { employees }\end{array}$ & t-value \\
\cline { 2 - 6 } & $\mathrm{M}$ & $\mathrm{SD}$ & $\mathrm{M}$ & $\mathrm{SD}$ & \\
\hline $\begin{array}{l}\text { I transferred the newly acquired knowledge to my } \\
\text { workplace }\end{array}$ & 4.02 & 0.723 & 4.05 & 0.736 & -0.321 \\
\hline $\begin{array}{l}\text { By the newly acquired knowledge I am able to contribute } \\
\text { in terms of enhanced working processes }\end{array}$ & 3.90 & 0.774 & 3.90 & 0.781 & -0.042 \\
\hline $\begin{array}{l}\text { I have become more capable therefore I have the } \\
\text { opportunity to participate in developmental activities }\end{array}$ & 3.40 & 0.892 & 3.54 & 0.794 & -1.347 \\
\hline $\begin{array}{l}\text { Through learning program I managed to develop problem } \\
\text { solving skills }\end{array}$ & 3.62 & 0.925 & 3.74 & 0.868 & -1.047 \\
\hline $\begin{array}{l}\text { The learning program enhanced my efficiency at work. } \\
\text { The learning program enabled me to more easily adapt }\end{array}$ & 3.68 & 0.909 & 3.84 & 0.748 & -1.538 \\
\hline $\begin{array}{l}\text { Th } \\
\text { to changes }\end{array}$ & 0.933 & 3.76 & 0.823 & $-2.163^{*}$ \\
\hline
\end{tabular}

${ }^{\star} p<0.05 ;{ }^{* \star} p<0.01$ 
The regression results ascertain stronger positive correlation between perceived organizational support for learning and learning results $(\beta=0.422, p<0.005)$ for the group of older employees compared to the group of younger employees $(\beta=0.200$, $\mathrm{p}<0.05)$. There is a weaker positive relationship of intrinsic motivation and learning results $(\beta=0.219, \mathrm{p}<0.05)$ for the group of older employees compared to younger employees $(\beta=0.448, p<0.005)$. Finally, the non-significant relationship of extrinsic motivation $(\beta=-0.230, \mathrm{~ns})$ for the group of older employees is compared to the negative correlation for the group of younger employees $(\beta=-0.176, p<0.05)$. The results thus partially support the H1b hypothesis meaning that the intrinsic motivation is more important predictor of younger workers learning results while extrinsic motivation is non-significant predictor for older workers learning results and negative predictor of younger workers' learning results.

The H3b hypothesis is fully supported because perceived organizational support for learning seems to be more important for older workers, as evident from Table 6. feel old at workplace because their knowledge "gets old" (and not because of their chronological age). However, employers are usually more inclined for favouring and supporting younger employees, when it comes to training and learning at workplace.

Thus, it is relevant to point out that our research results only partially support $\mathrm{H} 1 \mathrm{a}$, showing that older employees are equally inclined (motivated) towards learning and training at work as their younger colleagues when it comes to intrinsic learning motivation. However, younger employees express stronger extrinsic learning motivation in terms of getting promoted and earning respect from the company, going hand-in hand with the SST that reveals different priorities within life-span. Having also in mind the H1b, which was only partially supported (due to results showing that extrinsic motivation is negative predictor of younger workers' learning results), HRM should capitalize much more on intrinsic motivation of employees, regardless of their age.

The hypothesis that 'Younger employees achieve better learning results in compar-

Table 6

Linear regression analysis on learning results

\begin{tabular}{|c|c|c|c|c|}
\hline & \multicolumn{2}{|c|}{ Older employees } & \multicolumn{2}{|c|}{ Younger employees } \\
\hline & Beta & St. error & Beta & St. error \\
\hline Intrinsic learning motivation & $0.219^{*}$ & 0.097 & $0.448^{\star \star \star}$ & 0.077 \\
\hline Extrinsic learning motivation & -0.230 & 0.115 & $-0.176^{\star}$ & 0.074 \\
\hline $\begin{array}{l}\text { Organizational support for } \\
\text { learning }\end{array}$ & $0.422^{\star \star *}$ & 0.095 & $0.200^{*}$ & 0.084 \\
\hline $\mathrm{R}^{2}$ & \multicolumn{2}{|c|}{0.271} & \multicolumn{2}{|c|}{0.259} \\
\hline $\mathrm{F}$ & \multicolumn{2}{|c|}{$9.919^{* * *}$} & \multicolumn{2}{|c|}{$15.471^{\star \star \star}$} \\
\hline
\end{tabular}

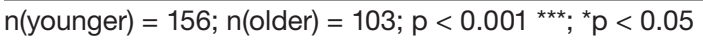

\section{DISCUSSION}

One of the main pillars constituting a complex age management model on organizational level is definitively knowledge management, because employees usually ison to their older counterparts' (H2) was rejected as well. This way, our research results help to combat numerous age stereotypes on older workers learning at workplace. Actually, the results of the current 
study are in line with the conclusions of several authors (Gegenfurtner and Varuas, 2012), who claim that workers maintain learning motivation throughout their working lives, and those (Ramscar, Hendrix, Shaoul, Milin and Baayen, 2014), who report that learning potential stays intact until an individual is in his/her 70s. Dordoni and Argentero (2015) findings point to the fact that usually older employees' learning motivation is not managed well.

Furthermore, our results uncover that stronger perceived organizational support for learning is offered to the group of younger workers (H3a: Perceived organizational support for learning is lower for the group of older workers compared to the group of younger workers). Actually, it should be just the opposite, namely organizational support for learning should be primarily offered to older employees, because - in accordance with SST (Carstensen, 1995) -knowledge gathering and career development do not seem so much relevant from older employees' perspective. Partially supported H1a also confirms this fact, because younger employees express higher extrinsic motivation in comparison with their older counterparts. Having in mind that in accordance with $\mathrm{H} 1 \mathrm{a}$, intrinsic motivation does not differ between the two groups of employees, organizational support should be oriented into inclusive workplace climate that embraces employees of all ages (and differences), and thus fulfilling intrinsic, emotionally driven human needs (in line with SDT).

Basically, the field of adult education has a long history of integrating learning/training with social action (e.g., Stein, 2006). Thus, trainers, who support older learners' autonomy, may enhance older employees' intrinsic motivation to learn by helping them to develop and pursue internalized goals related to learning.

The relevance of organizational support for older employees is also explained by confirming the $\mathrm{H} 3 \mathrm{~b}$ hypothesis, saying that organizational support for learning is more important for older workers in comparison with younger. Thus, we support many authors (Charness and Czaja 2019; Jeske and Stamov-Roßnagel, 2015; Olson and Jeske, 2019; Ravichandran, Cichy, Powers and Kirby, 2015), who also agree that especially older workers need substantial organizational support for learning.

\section{Theoretical contributions}

Although there is a vast body of literature on different age management measures (Žnidaršič, 2008), research on learning and training of older employees in terms of their employability is rather limited (Picchio and van Ours, 2013). In this context, our paper represents a significant contribution to HRM science and theory, when focusing on organizational age management theory.

Similar to the results of the previous researchers (Bowen \& Staudinger, 2012), our results contribute to contextual perspective (confirming the crucial role of organizational support for learning) for employee development, especially when managing older employees, and thus contributing to Social Learning Theory.

This study adds value to the realm of Theory of Human Motivation by dipper examination into motivation for learning of young vs. older employees and presenting some important specifics for both groups of workers. Our study is valuable for supporting several authors (for example Gegenfurtner and Varuas, 2012), who report that learning motivation is mostly maintained with age, while intrinsic motivation even strengthens (Bal and Dorenbosch, 2015; Gegenfurtner and Varuas, 2012). Our results also contribute to theory of motivation at workplace by presenting the findings, showing that extrinsic motivation for learning is not as important to older employees as it is to their younger colleagues. 
By investigating into intrinsic vs. extrinsic learning motivation separately, and afterwards coming to results that older employees do not differ from their younger colleagues regarding intrinsic learning motivation (while younger employees express slightly stronger extrinsic learning motivation), our work is of significant value added piece, especially for Organizational Learning Theory, because it gives an explanation for numerous ambiguous and conflicting previous findings about older employees' learning motivation.

Furthermore, on the basis of intrinsic and extrinsic learning motivation distinction, we were able to reasonably connect two basic psychological theories that influence on (older vs. younger) employees learning, namely SST and SDT into logical and meaningful story that offers the argumentation for the relevance of (perceived) organizational support for learning, that is of special importance for older employees.

\section{Practical implications}

Practical implications that arise out of our study are threefold. In accordance with common policy in developed countries that stimulates longer working lives, our study reminds policy-makers on macro-economic level that continuous learning and training of all employees should be enabled. Policy-makers should work more actively on debunking age stereotypes, including incorrect perceptions on older employees' motivation and capacity for learning. Concrete actions should involve applying measures (laws) to ensure equal opportunities for workplace training and development for all employees, regardless of their age. Considering that there exists a big gap between 'what is written down' and 'how it really works in companies' when it comes to equal opportunities for workplace training, this paper suggests better communication and cooperation between policy-makers and employers (HRM) in companies. The limited access to training programs is rather serious type of discrimination as Stypinska and Turek (2017) categorize it within the hard type of age discrimination in the workplace.

Debunking myths on older employees' training abilities and motivation, our paper brings an important message also to older workers: 'they have the same right to get educated and trained as they younger counterparts have'. Moreover, our paper can raise individual awareness for learning (self-efficacy) when we shed the light on many positive outcomes of getting involved in continuous learning and on the job training, starting from cognitive abilities maintenance to workability development/ improvement.

Regarding HRM practitioners, our results - again - help to dispel the myths about aging individuals. The HRM should abandon age stereotyping and discrimination based on chronological age when deciding who gets the opportunity to learn. In accordance with our results, showing that the learning results of younger workers are not better than those of the older workers, managers need to acknowledge that there is rationale for investing in older workers (learning), while considering the difference in motives and needs. For example, older workers do not decide to attend the training workshops to get promotion or salary raise as much as the younger workers do.

According with life-span development theories (e.g. Lang and Carstensen, 2002), older employees' growth and extrinsic motives weaken (in accordance with SST), while intrinsic motives increase (Kooij et al., 2017) or stay intact, especially when needs for autonomy, competence and relatedness are fulfilled (according to SDT). Thus, HRM can lean on SDT and develop organizational support for learning that would meet older employees' values and needs. Opposed from young, older workers prioritize emotionally meaningful 
goals. Referring to Gegenfutner and Vauras (2012), training programs (or learning opportunities) should offer the possibility for social interaction because the expectation of contact with peers seems to be emotionally meaningful, especially for older employees, providing them the sense of inclusiveness and relatedness (Olson \& Jeske, 2019). Bertolino, Truxillo and Fraccaroli (2011) also say that - different from young employees - who focus on training related to career development, older people look more toward generative roles, like mentoring and relationships with co-workers. For example, Burmeister et al. (2019) argue that the alignment between workers' age and their roles in knowledge transfer can generate motivational benefits. While receiving knowledge from older mentors is more closely aligned with younger workers' goal priorities (which is in line with SST), being a mentor to co-workers is more closely aligned with older workers' goal priorities.

HRM strategies (policies and actions) that demonstrate support for ongoing development of worker's skills and expansion of their knowledge are perceived as symbols of the organizations commitment to them and their continued effectiveness in their roles (Allen, Shore, \& Griffeth, 2003).

Here, it is reasonable to stress that HRM is a broader concept that includes organizational support (being understood as supervisors' and peer encouragement and support) but it is not limited to it.

By encouraging and supporting workers who seek to gain new insights, skills and knowledge on topics of interest, HRM plays crucial role in messaging the relevance of the training content, in creating inclusive learning practices ( $\mathrm{Ng} \&$ Feldman, 2012) and expressing more recent lifespan approaches to motivation and learning (Heckhausen et al., 2017). HRM is also responsible for design of training and development opportunities that regard including approaches that optimize learning for older workers (Jeske \& Stamov Roßnagel, 2012). Summing up, HRM actions should focus on generating a supportive learning climate (Froehlich, Segers \& van den Bossche, 2014; Olson \& Jeske, 2019) accompanied with the presence of resources that may facilitate learning (Jeske, Stamov Roßnagel, \& Strack, 2017).

By fostering learning self-efficacy (self-empowerment, self-control, and self-determination), stimulating independent learning, social interactions, contact with peers, and the opportunity to mentor and/or be mentored, most employees would like participating in trainings and will flourish at workplace, even when approaching retirement. Zwick (2015) also argues that older employees prefer and get higher returns from informal training with a clear focus on practical and relevant work problems. Thus, HRM should create unique strategies that are in line with specific needs of each age group of workers, which also goes handin-hand with both, SST and SDT theories.

HRM should consider that future time perspective and goal preferences are not fixed but are subject to contextual factors and can be changed (Lang \& Carstensen, 2002). Even small and subtle changes from workplace environment may encourage information and knowledge gathering or reduce avoidant tendencies. The success of such interventions rests on achieving a good match with individual goal priorities.

In terms of strengthening direct organizational support for learning, HRM should enhance communication between supervisors and employees, both with regard to the purpose and objectives of training, as well as the content and intensity of the workshops when it comes to shaping the goals of transferring knowledge to the workplace.

\section{Limitations}

Despite the contributions, this study is not without limitations. Recent economic crisis has negatively influenced on the per- 
ceived need for (older) employees and age management policies, especially on the organizational level. Moreover, stereotyping older employees (by employers) and 'the culture of early retirement' (that is still present among employees in post-transition countries) also present limitations of the current study.

The second set of limitations refers to our sample, namely consisting of: a) selection of companies, b) questionable comparability of behaviour when observing young vs. older employees that work in specific (different) industries, and c) the size and nature of the sample. Regarding the industry and the field of work, the problem that needs to be considered is twofold. First, the perception about being an 'older employee' is diametrically different from one industry to another. Secondly, within certain industries, it is more desirable to be older and having more experience. There are professions that are 'reserved' for older employees and younger cannot compete to get to those positions and vice versa.

Finally, self-reported measures of motivation and learning outcomes can also be considered as a limitation.

\section{Challenges for future research}

Since the data are cross-sectional, the causality cannot be inferred. That is why future research should adopt a longitudinal perspective, not just to establish causality, but also to tackle some new dynamics, such as the effects of training at work on strengthening positive organizational climate. Within learning process, employees do not develop only the competences that lead to greater efficiency at work (Rejc Buhovac, 2010), but also in lower fluctuation, lower absenteeism, increased loyalty to organization (Dermol, 2010), and even greater trust to one's supervisor as well as the co-workers (Peterson \& Spiker, 2005). It might even result in greater reputation of an organization that facilitates learning (Dermol, 2010).The additional constructs might help shedding light on the examined relationships, be it as possible boundary conditions or explanatory mechanisms.

Our research findings themselves are suggesting some other interesting directions for future research that would focus on employers, on developing and testing sustainable and efficient practices of adapting training and learning programs to the ever-changing (psychological) needs of the aging workforce, so that continuous learning of older employees would work to older employees' credit as well as for the good of the companies. Moreover, the role of direct supervisor should be further considered (is it commonly known that even a trainee with low initial motivation may become inspired to learn by a good teacher).

Further developing and evaluating lifelong learning theories and concepts for both age groups of employees (with the aim of supporting organizational and individual motivation intended to strengthen the links between learning and working processes) would aid to lifelong career planning.

Finally, there is still a lot of space left for investigation that would provide the in-depth understanding of older employees decision making when contemplating whether to engage in learning or not. Both, major groups of factors that influence older employees' continuous learning processes need to be considered, namely individual factors like age perceptions, motivation and attitude towards learning, experience and having learning goals as well as the contextual factors like workplace conditions, team climate, and learning atmosphere.

From the older employees' perspective, more research with a focus on potential benefits of longer working life for well-being in later phases of life (for example avoiding social isolation and dislocation), is urgently needed. 


\section{CONCLUSION}

The population and workforce aging ask for quick actions of age management at all levels, with special focus on lifelong learning. In accordance with focusing on organizational level the main contributions of our study can mostly be found in the comparison of older vs. younger employees when it comes to updating knowledge and workplace learning (training).

Although it seems to be of significant importance to achieve high levels of learning results of both age groups of workers (Bal, van Kleef \& Jansen, 2015; Stamov Roßnagel \& Jeske, 2017), it is of special relevance to constantly up-date older workers' knowledge to capitalize on their full potential. The results highlighted that older employees are willing and able to learn, if only they receive relevant organizational support. To sum up, our research results themselves are negative answer on the question regarding "is it ever too late to learn" and definitely talk in favour of investing into older employees while simultaneously developing inclusive and supportive learning environment.

Besides holding value for further academic investigation, our research results can also be beneficial for practitioners in the field under investigation, since they among others - shed light on the stereotypes regarding older employees learning that we all need to combat in the very near future. A value added of this paper lies in pointing on the role of organizational support for learning that can meaningfully integrate SST and SDT theories for enhancing older employees' learning. Again, the role of HRM in achieving desired results of learning at workplace is inevitable, while their supportive measures seem to play an important part in learning process, especially when targeting older employees.

\section{REFERENCES}

Aguinis, H., \& Kraiger, K. (2009). Benefits of training and development for individuals and teams, organizations, and society. Annual Review of Psychology, 60, 451-474. https://doi.org/10.1146/ annurev.psych.60.110707.163505

Armstrong-Stassen, M., \& Cattaneo, J. (2010). The effect of downsizing on organizational practices targeting older workers. Journal of Management Development, 29(4), 344-363. https://doi. org/10.1108/02621711011039150

Axelrad, H., Luski, I., \& Miki, M. (2013). Difficulties of integrating older workers into the labor market: exploring the Israeli labor market. International Journal of Social Economics, 40(12), 1058-1076. https://doi.org/10.1108/IJSE12-2011-0098

Bal, P. M., \& Dorenbosch, L. (2015). Age-related differences in the relations between individualized HRM and organisational performance: A large-scale employer survey. Human Resource Management Journal, 25(1), 41-61. https://doi. org/10.1111/1748-8583.12058

Bal, P. M., van Kleef, M., \& Jansen, P. G. W. (2015). The impact of career customization on work outcomes: Boundary conditions of manager support and employee age. Journal of Organizational Behavior, 36(3), 421-440. https://doi. org/10.1002/job.1998

Bandura, A. (1971). Social Learning Theory. New York: General Learning Corporation.

Bayl-Smith, P. H., \& Griffin, B. (2014). Age discrimination in the workplace: Identifying as a late-career worker and its relationship with engagement and intended retirement age. Journal of Applied Social Psychology, 44(9), 588-599. https://doi. org/10.1111/jasp.12251

Bertolino, M., Truxillo, D. M., \& Fraccaroli, F. (2011). Age as moderator of the relationship of proactive personality with training motivation, perceived career development from training, and training behavioral intentions. Journal of Organizational Behavior, 32(2), 248-263. https://doi. org/10.1002/job.670

Bowen, C. E., \& Staudinger, U. M. (2012). Relationship between age and promotion orientation depends on perceived older worker stereotypes. Journal of Gerontology: Series B Psychological Sciences and Social Sciences, 68(1), 59-63. https://doi.org/10.1093/geronb/gbs060

Burmeister, A., Wang, M., \& Hirschi, A. (2019). Understanding the motivational benefits of knowledge transfer for older and younger workers in 
age-diverse coworker dyads: an actor-partner interdependence model. Journal of Applied Psychology, 105(7), 748-759. https://doi.org/10.1037/ ap10000466

Carral, P., \& Alcover, C. M. (2019). Measuring age discrimination at work: Spanish adaptation and preliminary validation of the Nordic Age Discrimination Scale (NADS). International Journal of Environmental Research and Public Health, 16(8), 1431. https://doi.org/10.3390/ ijerph16081431

Carstensen, L. L. (1995). Evidence for a life-span theory of socioemotional selectivity. Current Directions in Psychological Science, 4(5), 151-156. https://doi.org/10.1111/1467-8721.ep11512261

Charness, N., \& Czaja, S. J. (2019). Age and technology for work. In K. S. Schultz \& G. A. Adams (Eds.), Ageing and Work in the $21^{\text {st }}$ Century (pp. 234-254). New York: Routledge.

Chatterjee, A., Pereira, A., \& Bates, R. (2018). Impact of individual perception of organizational culture on the learning transfer environment. International Journal of Training and Development, 22(1), 15-33. https://doi.org/10.1111/ijtd.12116

Dermol, V. (2010). Usposabljanja zaposlenih ter njihov vpliv na organizacijsko učenje in uspešnost $v$ slovenskih storitvenih podjetjih [doktorska disertacija]. Ekonomska fakulteta, Ljubljana.

Diamantidis, A. D., \& Chatzoglou, P. D. (2014). Employee post-training behaviour and performance: Evaluating the results of the training process. International Journal of Training and Development, 18(3), 149-170. https://doi.org/10.1111/ ijtd.12034

Dordoni, P., \& Argentero, P. (2015). When age stereotypes are employment barriers: A conceptual analysis and a literature review on older workers stereotypes. Aging International, 40(4), 393-412. https://doi.org/10.1007/s12126-015-9222-6

Fregonese, C., Caputo, A., \& Langher, V. (2018). Italian translation of the questionnaire for professional training evaluation. International Journal of Training and Development, 22(1), 34-50. https://doi.org/10.1111/ijtd.12117

Freund, A. M. (2006). Age-differential motivational consequences of optimization versus compensation focus in younger and older adults. Psychology and Aging, 21(2), 240-252. https://doi. org/10.1037/0882-7974.21.2.240

Froehlich, D. E., Segers, M. S. R., \& van den Bossche, P. (2014). Informal workplace learning in Austrian banks: The influence of learning approach, leadership style, and organizational learning culture on managers' learning outcomes. Human
Resource Development Quarterly, 25(1), 29-57. https://doi.org/10.1002/hrdq.21173

Gaillard, M., \& Desmette, D. (2010). (In)validating stereotypes about older workers influences their intentions to retire early and to learn and develop. Basic Applied Social Psychology, 32(1), 8698. https://doi.org/10.1080/01973530903435763

Gegenfurtner, A., \& Vauras, M. (2012). Age-related differences in the relation between motivation to learn and transfer of training in adult continuing education. Contemporary Educational Psychology, 37(1), 33-46. https://doi.org/10.1016/j. cedpsych.2011.09.003

Griffin, R. P. (2011). Workplace learning evaluation: A conceptual model and framework. Industrial and Commercial Training, 43(3), 172-178. https:// doi.org/10.1108/00197851111123631

Guerrero, S., \& Sire, B. (2001). Motivation to train from the workers' perspective: example of French companies. The International Journal of Human Resource Management, 12(6), 988-1004. https:// doi.org/10.1080/713769684

Harris, K., Krygsman, S., Waschenko, J., \& Laliberte Rudman, D. (2018). Ageism and the older worker: A scoping review. Gerontology, 58(2), e1-e14. https://doi.org/10.1093/geront/gnw194

Hashim, J., \& Wok, S. (2014). Competence, performance and trainability of older workers of higher educational institutions in Malaysia. Employee Relations, 36(1), 82 $\square 106$.

Hasselhorn, H. M., \& Apt, W. (2015). Understanding employment participation of older workers: Creating a knowledge base for future labour market challenges. Berlin: Federal Ministry of Labour and Social Affairs.

Heckhausen, J., Shane, J., \& Kanfer, R. (2017). Competence and motivation at work throughout adulthood: Making the most of changing capacities and opportunities. In A. J. Elliot, C. S. Dweck \& D. S. Yeager (Eds.), Handbook of competence and motivation (2nd Ed.) (pp. 449-470). New York: The Guilford Press.

Hvalič Erzetič, B. (2014). Vpliv izobraževanja in usposabljanja na podjetnikovo uspešnost [doktorska disertacija]. Ekonomska fakulteta, Ljubljana.

Jeske, D., \& Stamov-Roßnagel, C. S. (2015). Learning capability and performance in later working life: Towards a contextual view. Education + Training, 57(4), 378-391. https://doi.org/10.1108/ ET-08-2013-0107

Jeske, D., \& Stamov Roßnagel, C. (2016). Understanding what drives informal learning at work: A resource-based view. International Journal of 
Management, Knowledge, and Learning, 5(2), 25-44. https://ideas.repec.org/a/isv/jouijm/v5y2015i2p145-165.html

Jeske, D., Stamov Roßnagel, C., \& Strack, J. (2017). Training older workers: Resource-oriented strategies. International Journal of Training \& Development, 21(2), 167-176. https://doi.org/10.1111/ ijtd. 12100

Karpinska, K., Henkens, K., Schippers, J., \& Wang, M. (2015). Training opportunities for older workers in the Netherlands: A Vignette Study. Research in Social Stratification and Mobility, 41, 105-114. https://doi.org/10.1016/j. rssm.2015.03.002

Kastelec, K. (2013). Analiza izobraževanja zaposlenih $v \breve{S} Z$ - Vleka in tehnika [magistrska naloga]. Ekonomska fakulteta, Ljubljana.

Kerman, S. C., \& Keenan, T. A. (2017). The multi-generational labor force: Perceptions of jobs among Millennials, Gen-Xers, and Boomers. Washington: AARP Research.

Kirkpatrick, D. L., \& Kirkpatrick, J.D. (2006). Evaluating training programs: The four levels. San Francisco: Berrett-Koehler Publishers.

Kooij, D. T. A. M. (2015). Successful aging at work: The active role of employees. Work, Aging and Retirement, 1(4), 309-319. https://doi.org/10.1093/ workar/wav018

Kooij, D. T. A. M., van Woerkom, M., Wilkenloh, J., Dorenbosch, L. W., \& Denissen, J. J. A. (2017). Job crafting towards strengths and interests: The effects of a job crafting intervention on person-job fit and the role of age. Journal of Applied Psychology, 102(6), 971-981. https://doi. org/10.1037/ap10000194

Kump, S., \& Jelenc Krašovec, S. (2010). Prestari za učenje? Vzorci izobraževanja in učenja starih. Ljubljana: Pedagoški inštitut.

Lang, F. R., \& Carstensen, L. L. (2002). Time counts: Future time perspective, goals, and social relationships. Psychology \& Aging, 17(1), 125-139. https://doi.org/10.1037/0882-7974.17.1.125

Maslow, A. H. (1943). A theory of human motivation. Psychological Review, 50(4), 370-396. https://doi. org/10.1037/h0054346

Massenberg, A. C., Spurk, D., \& Kauffeld, S. (2015). Social support at the workplace, motivation to transfer and training transfer: A multilevel indirect effects model. International Journal of Training and Development, 19(3), 161-178. https://doi.org/10.1111/ijtd.12054

Midtsundstad, T. (2019). A review of the research literature on adult learning and employability.
European Journal of Education, 54(1), 13-29. https://doi.org/10.1111/ejed.12321

Minbaeva, D. B. (2008). HRM practices affecting extrinsic and intrinsic motivation of knowledge receivers and their effect on intra-MNC knowledge transfer. International Business Review, 17(6), 703-713. https://doi.org/10.1016/j.ibusrev.2008.08.001

Muijnck, J. A., \& Zwinkels, W. S. (2002). Older employees in SME's: A literature review on the use of older employees. In Onderzoek voor Bedrijf \& Beleid, Zoetermeer. The SME-Organization, EIM.

Neirotti, P., \& Paolucci, E. (2013). Why do firms train? Empirical evidence on the relationship between training and technological and organizational change. International Journal of Training and Development, 17(2), 93-115. https://doi. org/10.1111/ijtd.12003

Ng, T. W. H., \& Feldman, D. C. (2012). Evaluating six common stereotypes about older workers with meta-analytical data. Personnel Psychology, 65(4), 821-858. https://doi.org/10.1111/ peps. 12003

Organisation for Economic Co-operation and Development. (2005). Ageing and employment policies. Paris: OECD.

Organisation for Economic Co-operation and Development. (2015). Recommendation of the Council of Ageing and Employment Policies. Available at https//www.oecd.org/els/emp/Ageing-Recommendation.pdf

Organisation for Economic Co-operation and Development. (2017). Preventing ageing unequally. Paris: OECD.

Olson, D. A., \& Jeske, D. (2019). Employee development and training issues related to the aging workforce. In K. S. Shultz \& G. A. Adams (Eds.), Aging and Work in the 21st Century (pp. 187202). London: Routledge.

Peterson, S. J., \& Spiker, B. K. (2005). Establishing the positive contributory value of older workers: A positive psychology perspective. Organizational Dynamics, 34(2), 153-167. https://doi. org/10.1016/j.orgdyn.2005.03.002

Picchio, M., \& van Ours, J. C. (2013). Retaining through training even for older workers. Economics of Education Review, 32, 29-48. https://doi. org/10.1016/j.econedurev.2012.08.004

Pitt-Catsouphes, M., \& Smyer, M. (2005). Older workers: What keeps them working? Chestnut Hill, MA: Boston College. http://hdl.handle. net/2345/3525 
Ramscar, M., Hendrix, P., Shaoul, C., Milin, P., \& Baayen, H. (2014). The myth of cognitive decline: Non-linear dynamics of lifelong learning. Topics in Cognitive Science, 6(1), 5-42. https:// doi.org/10.1111/tops.12078

Ravichandran, S., Cichy, K. E., Powers, M., \& Kirby, K. (2015). Exploring the training needs of older workers in the foodservice industry. International Journal of Hospitality Management, 44, 157164. https://doi.org/10.1016/j.ijhm.2014.10.003

Rejc Buhovac, A. (2010). Kazalci merjenja uspešnosti izobraževanja v organizacijah: model za merjenje uspešnosti vlaganja $\mathrm{v}$ zaposlene. HRM: strokovna revija za ravnanje z ljudmi pri delu, 8(38), 6-14.

Rudolph, C. W., \& Zacher, H. (2015). Intergenerational perceptions and conflicts in multi-age and multigenerational work environments. In L. M. Finkelstein, D. M. Truxillo, F. Fraccaroli \& R. Kanfer (Eds.), Facing the challenges of a multiage workforce: A use-inspired approach (pp. 253-282). New York: Routledge.

Ryan, R. M., \& Deci, E. L. (2000a). Intrinsic and extrinsic motivations: Classic definitions and new directions. Contemporary Educational Psychology, 25(1), 64-67.https://doi.org/10.1006/ ceps.1999.1020

Ryan, R. M., \& Deci, E. L. (2000b). Self-determination theory and the facilitation of intrinsic motivation, social development, and well-being. American Psychologist. 55(1), 68-78. https://doi. org/10.1037/0003-066X.55.1.68

Salas, E., Tannenbaum, S. I., Kraiger, K., \& SmithJentsch, K. A. (2012). The science of training and development in organizations: What matters in practice. Psychological Science in the Public Interest, 13(2), 74-101. https://doi. org/10.1177/1529100612436661

Setti, I., Dordoni, P., Picoli, B. Bellotto, M., \& Argentero, P. (2015). Proactive personality and training motivation among older workers: A mediational model of goal orientation. European Journal of Training and Development, 39(8), 681-699. https://doi.org/10.1108/EJTD-03-2015-0018

Spagnoli, P., Caetano, A., \& Santos, S. C. (2012). Satisfaction with job aspects: Do patterns change over time?. Journal of Business Research,
65(5), 609-616. https://doi.org/10.1016/j.jbusres.2011.02.048

Stamov Roßnagel, C., \& Jeske, D. (2017). Successful ageing in the workplace. A resources-oriented intervention perspective. In L. Riby (Ed.), Handbook of Gerontology Research Methods (pp. 95-117). London: Routledge.

Stein, D.S. (2006). Establishing conceptual boundaries: What is an adult education project?. New Horizons in Adult Education and Human Resource Development, 20(1), 32-42. https://doi. org/10.1002/nha3.10241

Stypinska, J., \& Turek, K. (2017). Hard and soft age discrimination: The dual nature of workplace discrimination. European Journal of Aging, 14(1), 49-61.https://doi.org/10.1007/s10433-016-0407-y

Tims, M., Bakker, A. B., \& Derks, D. (2012). Development and validity of the job crafting scale. Journal of Vocational Behavior, 80(1), 173-186. https://doi.org/10.1016/j.jvb.2011.05.009

van Gerwen, N., Buskens, V., \& van der Lippe, T. (2018). Employee cooperative behavior in organizations: A vignette experiment on the relationship between training and helping intentions. International Journal of Training and Development, 22(3), 192-209. https://doi.org/10.1111/ ijtd. 12128

Voss, P., Wolff, J. K., \& Rothermund, K. (2017). Relations between views on ageing and perceived age discrimination: A domain-specific perspective. European Journal of Aging, 14(1), 5-15. https:// doi.org/10.1007/s10433-016-0381-4

Wanberg, C. R., Kanfer, R., Hamann, D. J., \& Zhang, Z. (2016). Age and reemployment success after job loss: An integrative model and meta-analysis. Psychological Bulletin, 142(4), 400-426. https:// doi.org/10.1037/bul0000019

Wang, M., Olson, D. A., \& Shultz, K. S. (2013). Mid and late career issues: An integrative perspective. New York: Routledge.

Zwick, T. (2015). Training older employees: What is effective?. International Journal of Manpower, 36(2), 136-150. https://doi.org/10.1108/IJM-092012-0138

Žnidaršič, J. (2008). Management starosti: Organizacijski model aktivnega staranja [doktorska disertacija]. Ekonomska fakulteta, Ljubljana. 


\title{
Sažetak \\ NIKADA NIJE PREKASNO ZA UČENJE: ULOGA ORGANIZACIJSKE PODRŠKE U UČENJU STARIJIH ZAPOSLENIKA
}

\author{
Jana Žnidaršič \\ Ekonomska fakulteta \\ Univerza v Ljubljani \\ Ljubljana, Slovenija
}

Mojca Kogovšek

Metka Kogovšek

Grm Novo mesto - center biotehnike in turizma

Novo mesto, Slovenija

\section{Irena Ograjenšek \\ Ekonomska fakulteta \\ Univerza v Ljubljani \\ Ljubljana, Slovenija}

U posljednjim desetljećima cjeloživotno učenje zadobiva sve više pozornosti zbog svoje ključne uloge u socijalnim mjerama za poticanje aktivnog starenja. Zbog brojnih kontroverznih rezultata istraživanja o trajnom učenju starijih zaposlenika, naš je rad usmjeren na usporedbu starijih $i$ mlađih zaposlenika u pogledu njihove motivacije (spremnosti) za učenje i na ishode koji su rezultat procesa učenja i usavršavanja. Naši rezultati ne pokazuju statistički značajne razlike u rezultatima učenja obje grupe zaposlenika niti u općoj motivaciji za učenje. Ipak, rezultati pokazuju da se stariji zaposlenici manje bave učenjem kako bi ispunili svoje karijerne ciljeve, a više kako bi unaprijedili učinkovitost u radu, te da bi olakšali prijenos znanja na radnom mjestu. Dodatno se razmatra ključna uloga percipirane organizacijske podrške trajnog učenja i usavršavanja starijih zaposlenika na radnom mjestu.

Ključne riječi: starenje radne snage, stariji zaposlenici, motivacija za učenje, upravljanje starenjem. 